\title{
The spring bloom and its impact on benthic mineralisation rates in western Irish Sea sediments
}

\author{
M. Trimmer ${ }^{1}$, R. J. Gowen ${ }^{2}$, B. M. Stewart ${ }^{2}$, D. B. Nedwell ${ }^{1, *}$ \\ 'Department of Biological Sciences, University of Essex, Colchester CO4 3SQ, United Kingdom \\ ${ }^{2}$ Agricultural and Environmental Science Division, Department of Agriculture for Northern Ireland, Newforge Lane. \\ Belfast ET9 5PX, United Kingdom
}

\begin{abstract}
The impact of the spring bloom on benthic remineralisation rates was studied in offshore waters of the western Irish Sea during 1998. Initiation of the spring bloom coincided with the onset of thermal stratification at the end of April. Peak chlorophyll biomass $\left(6.48 \mathrm{mg} \mathrm{chl} \mathrm{m}^{-3}\right)$ and algal standing stock (145.0 $\mathrm{mg} \mathrm{chl} \mathrm{m}^{-2}$ ) were measured on May 11, and the bloom lasted approximately $1 \mathrm{mo}$. Sed-

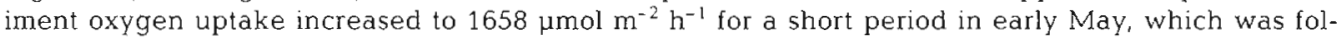

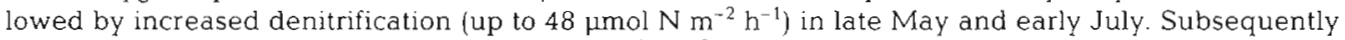
sulphate reduction increased (up to $83 \mu \mathrm{mol} \mathrm{SO}{ }_{4}{ }^{2-} \mathrm{m}^{-2} \mathrm{~h}^{-1}$ ) in early July. Efflux of nitrate remained low but constant $\left(10 \mu \mathrm{mol} \mathrm{m} \mathrm{m}^{-2} \mathrm{~h}^{-1}\right)$ throughout the study, accounting for $27 \%$ of ammonified organic $\mathrm{N}$, with the remaining $63 \%$ being denitrified. Sediment depth profiles of chlorophyll and phaeopigment showed deep $(>30 \mathrm{~cm})$ mixing of phytodetritus into the sediment in early July, which may explain the high rates of sulphate reduction measured at this time. Evidence of a large phytodetrital flux to the benthos during spring 1998 was limited. Deepening of chlorophyll isopleths suggested sinking of algae in early May, although sediment pigment concentrations indicated a continual but low input. Benthic oxygen consumption represented $46 \%$ of total spring phytoplankton production or $61 \%$ of new production and approximately balanced the calculated flux of detrital carbon (C) to the benthos. The impact of detrital $\mathrm{C}$ (assumed to be largely phytodetritus immediately after the spring bloom) on the benthos was short lived, being rapidly remineralised, and in turn little spring production would have been available for secondary production, e.g. Nephrops norvegica. In such years, benthic production, particularly that of $N$. norvegica, must be supported by phytoplankton production which takes place after the bloom or by detrital $C$ which is advected into the area following the breakdown of the gyre.
\end{abstract}

KEY WORDS: Spring bloom - Benthic mineralisation $\cdot$ Nutrient exchange $\cdot$ Secondary production

\section{INTRODUCTION}

It has been estimated that $83 \%$ of all oceanic benthic remineralisation of organically bound nutrients occurs in shelf sediments (Jørgensen 1983). However, quantifying the linkage between water column production and benthic remineralisation may be complicated by the influence of temperature on microbial activity and transport of particulate material by advection before settling.

In the deeper $(\sim 90 \mathrm{~m})$ waters of the western Irish Sea, where tidal flows are weak, the annual cycle of solar

\footnotetext{
•Addressee for correspondence. E-mail: nedwd@essex.ac.uk
}

heating results in the formation of a region of thermally stratified water (Simpson \& Hunter 1974, Richardson et al. 1985, Gowen et al. 1995). Partial isolation of the bottom water results in temperature increases of only $\sim 1.5^{\circ} \mathrm{C}$ during spring and summer (Gowen et al. 1995). Vertical gradients in density associated with stratification create a cyclonic gyre of near-surface water (Hill et al. 1994). This gyre appears to retain planktonic animals within the western Irish Sea (White et al. 1988, Dickey-Collas et al. 1996, Hill et al. 1996) and may also limit the import and export of water column production into and from the region. As such the western Irish Sea provides a suitable location at which to study the response of the benthos to changes in primary production in the overlying water column. 
An additional feature of the region is the muddy sediment of the gyre which is the habitat for a commercially important Nephrops norvegica fishery. The annual yield from this fishery is $-8000 \mathrm{t}$, which has a value of $\sim £ 10$ million (Briggs 1997). It is assumed that this $N$. norvegica secondary production is largely dependent on total seasonal primary production (April to September) in the overlying water, which has been estimated as $140 \mathrm{~g} \mathrm{C} \mathrm{m}^{-2}$ (Gowen \& Bloomfield 1996).

The influence of settling detritus on benthic microbial processes in the western Irish Sea is largely unknown and the aims of the current study were to (1) quantify the productivity of the spring bloom, (2) assess the subsequent impact of this production on benthic respiration and (3) quantify the fate of nutrients in the benthos.

\section{MATERIALS AND METHODS}

Sample site. Nine surveys were conducted at a deep $(93 \mathrm{~m})$ station in the western Irish Sea (Fig. 1) between February and July 1998 onboard the RV 'Lough Foyle'. Preliminary measurements of sedimentary oxygen uptake, denitrification and sediment particle size distribution were made during cruises on the RV 'Cirolina' in October 1996 and April and May 1997. During each RV 'Lough Foyle' cruise a vertical profile of temperature and salinity was recorded using a Hydro-Bios CTD mounted on a rosette sampler. The CTD was calibrated for salinity by salinometer measurements on discrete water samples and for temperature by reversing thermometers.

Water column characteristics. Recording thermistors (Minilog, Hydrosphere UK Ltd, Aldershot, UK) secured to the instrument arm of a U-shaped mooring recorded temperature from a range of depths throughout the study. Data, recorded at 10 min intervals, were averaged to give mean daily water temperature. Water samples for measurement of phytoplankton chlorophyll and dissolved inorganic nitrate (+ nitrite) were collected from depths selected on the basis of the vertical distribution of temperature and in situ fluorescence measured by a Chelsea Instruments Mk III Aquatracka fluorometer mounted on the rosette sampler. Chlorophyll was determined using the method of Tett (1987). Known volumes of water between 0.1 and 0.251 were filtered through GF/F glass fibre filters. Algal pigments were extracted in neutralised $90 \%$ acetone for $24 \mathrm{~h}$ at $4^{\circ} \mathrm{C}$ in the dark. Measurements of extracted chlorophyll fluorescence were made (before and after acidification with $8 \%$ hydrochloric acid to distinguish phaeopigments) using a Turner Designs Model 10 filter fluorometer. The average depth of the euphotic zone was taken to be $23 \mathrm{~m}$ (Gowen et al.

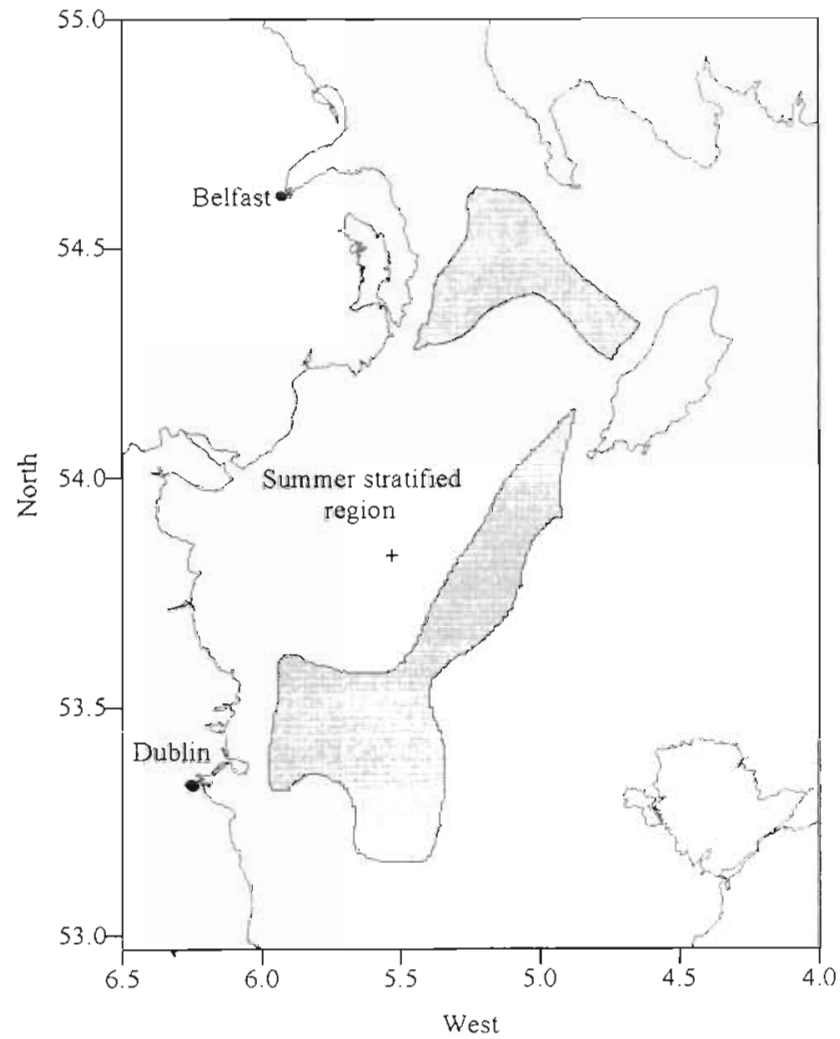

Fig. 1. Map of the western Irish Sea showing location $(t)$ of the sampling site and mooring station. Shaded areas show the approximate locations of the tidal mixing fronts which separate the summer stratified regions from mixed waters

1995) and chlorophyll standing stock within the euphotic zone was determined by interpolation of extracted chlorophyll values. Water samples for determination of dissolved inorganic nitrate (+ nitrite) were stored frozen until analysis using a Bran and Luebbe segmented continuous-flow analyser (TRAACS) employing a colorimetric method (Stewart \& Elliot 1996).

Sediment characteristics. Sediment collection and storage: Sediment samples were collected using a $0.1 \mathrm{~m}^{2}$ box corer (Spartel Ltd). Six large sediment cores ( $-30 \mathrm{~cm}$ deep) were subsampled from the box corer using perspex core tubes ( $65 \mathrm{~cm}$ long $\times 8 \mathrm{~cm}$ i.d.), each sealed at the bottom with a silicon rubber bung. In addition, small cores of sediment $(\sim 12$ to $18 \mathrm{~cm}$ deep depending on usage) were collected in perspex core tubes $(20 \mathrm{~cm}$ long $\times 2.4 \mathrm{~cm}$ i.d.). Four small core tubes (for sulphate reduction) had injection ports at $1 \mathrm{~cm}$ intervals, sealed with silicon sealer. Site water collected from close to the sea-bed using the rosette sampler was gently reintroduced over the surface of each core to give a final volume of $\sim 500 \mathrm{mI}$ in the large cores and $100 \mathrm{ml}$ in each of the small cores. The cores were 
completely submerged in aerated site water at in situ temperature and allowed to re-equilibrate for 2 to $3 \mathrm{~h}$.

Sediment particle size and porosity: Particle size distribution was measured in a single small sediment core extruded and sectioned at $1 \mathrm{~cm}$ depths from 0 to $10 \mathrm{~cm}$ during May 1996. The sections were rinsed with deionised water to remove salt, freeze-dried and weighed. Each sample was then completely re-suspended in deionised water, using an ultrasonic bath to thoroughly disperse the particles and wet sieved through stainless steel mesh from $2 \mathrm{~mm}$ to $63 \mu \mathrm{m}$ (Endecotts Ltd, London, UK). Each fraction was redried and expressed as a percentage of the original total dry weight. A single small sediment core was used to determine porosity at $0-5 \mathrm{~cm}, 6-10 \mathrm{~cm}$ and $11-15 \mathrm{~cm}$ on each sampling occasion in 1998. Known volumes of sediment were extruded, weighed, dried to a constant weight and then reweighed.

Sediment organic carbon, total nitrogen and chlorophyll pigments: Organic carbon, total nitrogen and sediment pigment concentrations were measured in the upper $1 \mathrm{~cm}$ of small sediment cores collected on each occasion. In July 1998, a depth profile $(0-10,20$ and $30 \mathrm{~cm}$ ) of pigments was measured. For organic $\mathrm{C}$ and $\mathrm{N}$, samples were stored frozen. Before analysis using a Carlo Erba NA 1500 NC, CHN analyser, samples were homogenised with hydrochloric acid $(5 \mathrm{ml}$ $1 \mathrm{M}$ ) to remove carbonate. Small sediment cores were subsampled using a $50 \mathrm{ml}$ syringe barrel, extruded, and $1 \mathrm{~cm}$ depth horizons collected. Pigments were extracted for $24 \mathrm{~h}$ in the dark using acetone $(40 \mathrm{ml}$, $90 \%$ ) and measured by the fluorometric method described above. Sediment pigments were expressed as $\mathrm{mg}$ chlorophyll or phaeopigment $\mathrm{m}^{-2}$ for each $1 \mathrm{~cm}$ thick depth horizon

Sediment porewater concentrations of sulphate: Two small sediment cores were used to determine porewater concentrations of sulphate at the same depths as the porosity measurements. The extruded sediment samples were centrifuged $(1050 \times g$ for 5 min) and the supernatant drawn off with a syringe, filtered and frozen as above. Sulphate concentrations were analysed by ion exchange chromatography (series 2000 i, Dionex Corp, Sunnyvale, California, USA), with a $1.7 \mathrm{mM} \mathrm{NaHCO}$ and $1.8 \mathrm{mM} \mathrm{Na}_{2} \mathrm{CO}_{3}$ eluent, at a flow rate of $3 \mathrm{ml} \mathrm{min}^{-1}$ and a $0.07 \%$ solution $(\mathrm{v} / \mathrm{v})$ of concentrated $\mathrm{H}_{2} \mathrm{SO}_{4}$ regenerant at a flow rate of $8 \mathrm{ml} \mathrm{min}^{-1}$. Peak areas of samples were compared to those of known standards.

Sedimentary rate measurements. Oxygen uptake: Three of the large core tubes were capped and completely water-filled to exclude air bubbles. A midwater-column sample $(20 \mathrm{ml})$ was then drawn off into a gas-tight syringe, gently transferred to an Exetainer (12 ml, Labco Ltd, High Wycombe, UK) and fixed for
'Winkler' analysis of dissolved oxygen. The water column in each tube was stirred with an induction motor driving a magnetic follower. The rates of benthic $\mathrm{O}_{2}$ uptake were measured using dissolved $\mathrm{O}_{2}$ electrodes connected to a computer via a 6 channel oxygen meter (Nedwell \& Trimmer 1996). The onscreen computer logging enabled continuous monitoring of the oxygen levels in the water column and further facilitated statistical analyses for linearity with respect to time. Significant rates of oxygen uptake $(p<0.05)$ could usually be determined within $4 \mathrm{~h}$.

Nutrient exchange: The remaining 3 large core tubes were capped, but a headspace $(50 \mathrm{ml})$ was left in place. Triplicate water samples $(500 \mathrm{ml})$, with no sediment present, were controls for water column processes in the absence of sediment-water exchange. An air stream was then attached to each cap to aerate and gently mix the water column. A water sample $(20 \mathrm{ml})$ was taken from each flux chamber through a sample port, filtered $\left(0.2 \mu \mathrm{m}\right.$ Minisart Plus ${ }^{\mathrm{TM}}$, Sartorius UK Ltd) and frozen at $-20^{\circ} \mathrm{C}$ prior to analyses, and then at every 2 to $4 \mathrm{~h}$ for $24 \mathrm{~h}$. On each occasion samples were analysed for nitrate, nitrite, ammonium, urea, silicate and phosphate using the TRAACS analyser as described above.

Sulphate reduction: Four of the small sediment cores were used to measure rates of sulphate reduction using a ${ }^{35} \mathrm{SO}_{4}{ }^{2-}$ radiotracer technique (Sorokin 1962). Each core was injected at $1 \mathrm{~cm}$ intervals down to $15 \mathrm{~cm}$ with sodium ${ }^{35} \mathrm{~S}$-sulphate solution $(10 \mu \mathrm{l} ; 37 \mathrm{kBq}$ [1 $\mu \mathrm{Ci}$ ], specific activity $38.6 \mathrm{TBq} \mathrm{mmol}^{-1}$; Amersham International Ltd, Amersham, UK) made up in ultra high purity (UHP) water. One core was immediately fixed as a $T_{0}$ control (see below) and the other 3 cores were incubated for 16 to $24 \mathrm{~h}$ at in situ temperature. Each core was then extruded, sectioned at $0-5 \mathrm{~cm}$, 6-10 $\mathrm{cm}$ and $11-15 \mathrm{~cm}$, homogenised with zinc acetate solution $(100 \mathrm{ml}$ of $5 \% \mathrm{w} / \mathrm{v})$, and frozen at $-20^{\circ} \mathrm{C}$.

After thawing, the fixed subsamples $(50 \mathrm{ml}$ ) of sediment were digested (Nedwell et al. 1993) to recover both acid volatile sulphides (AVS) and tin-reducible sulphides (TRS); which includes pyrite (Skyring 1985, Nedwell \& Takii 1988). The hydrogen sulphide evolved from the digested samples was collected in 2 serial zinc acetate traps $(40 \mathrm{ml}$ of $1 \% \mathrm{w} / \mathrm{v})$. The slurry remaining after digestion of each sediment sample was centrifuged, decanted off, and made up to a known volume $(250 \mathrm{ml})$. Duplicate subsamples from the zinc acetate traps $(2 \mathrm{ml})$ and the residual sediment digests $(0.12 \mathrm{ml}+1.88 \mathrm{ml}$ UHP water $)$ were added to scintillation fluid ( $2 \mathrm{ml}$ Instagel, Packard Instrument Co, UK) and the radioactivity counted in a scintillation counter (Rackbeta, LKB Broma, Sweden) with an external standard to correct for quenching. The ratio of ${ }^{35}$ sulphide to ${ }^{35}$ sulphate was used to calculate rates of sulphate 
reduction according to Fossing \& Jørgensen (1989), using the measured porosity values and sulphate concentrations.

Denitrification: Nine of the small sediment cores were used to measure denitrification rates using the ${ }^{15} \mathrm{NO}_{3}{ }^{-}$isotope pairing technique of Nielsen (1992) This technique enables differentiation between denitrification supported by the uptake of nitrate from the overlying water $\left(D_{w}\right)$ and that coupled to nitrification of porewater $\mathrm{NH}_{4}{ }^{+}\left(\mathrm{D}_{\mathrm{n}}\right)$. Six of the 9 cores were spiked by addition of ${ }^{15} \mathrm{NO}_{3}{ }^{-}\left(10 \mathrm{mM} \mathrm{Na}{ }^{15} \mathrm{NO}_{3}{ }^{-}\right.$[99.3 atom \%, Europa, Crewe, UK]) into the overlying water, to give a final $\mathrm{NO}_{3}{ }^{-}$concentration of 40 to $50 \mu \mathrm{M}$, and left to equilibrate for $0.5 \mathrm{~h}$ (Rysgaard et al. 1995). An initial trial was carried out over a range of ${ }^{15} \mathrm{NO}_{3}{ }^{-}$concentrations $(10$ to $50 \mu \mathrm{M})$ to assess the effect of elevated $\mathrm{NO}_{3}{ }^{-}$ concentrations on in situ rates of denitrification. Water samples $(2 \mathrm{ml})$ were then collected from all cores to determine the ${ }^{14} \mathrm{NO}_{3}{ }^{-}:{ }^{15} \mathrm{NO}_{3}{ }^{-}$ratio in the overlying water of the treatment cores, filtered and frozen at $-20^{\circ} \mathrm{C}$ prior to analyses (see above). The sediment in the 3 reference cores was then gently mixed with the overlying water and a slurry sample $(20 \mathrm{ml})$ carefully drawn off into an Exetainer (12 ml, Labco Ltd, High Wycombe, UK) containing $\mathrm{ZnCl}$ solution $(500 \mu \mathrm{l}, 25 \% \mathrm{w} / \mathrm{v})$ and sealed. The ${ }^{15} \mathrm{NO}_{3}{ }^{-}$enriched cores were sealed and incubated in the dark at the in situ temperature, with gentle stirring $(\sim 60 \mathrm{rpm})$ of the water column for $6 \mathrm{~h}$. The onscreen data logging in the parallel oxygen uptake cores ensured that the concentration of oxygen in the overlying water never fell below $80 \%$ of air saturation. Following incubation, the ${ }^{15} \mathrm{NO}_{3}{ }^{-}$enriched cores were processed in the same way as the reference cores.

All the slurry samples were sent to the National Environmental Research Institute, Silkeborg, Denmark, to be analysed for relative abundance and concentration of ${ }^{28} \mathrm{~N}_{2},{ }^{29} \mathrm{~N}_{2}$ and ${ }^{30} \mathrm{~N}_{2}$ on a gas chromatograph coupled to a dual inlet isotope ratio mass spectrometer (Europa Instruments, Crewe, UK). Denitrification rates were calculated according to Nielsen (1992).

Fig. 2. Contour plots of (A) temperature at $0.5^{\circ} \mathrm{C}$ intervals, (B) nitrate (+ nitrite) at $1 \mu \mathrm{M}$ intervals and (C) chlorophyll (mg $\mathrm{m}^{3}$ ). The chlorophyll contour intervals are a geometric progression which represents a doubling of biomass 


\section{RESULTS}

\section{Water column characteristics}

\section{Thermal structure of the water column}

There was little evidence of any significant warming of near surface waters during March and early April, and during this period vertical gradients in temperature were $\leq 0.2^{\circ} \mathrm{C}$ (Fig. 2A). Thermal stratification of the water column began in late April and by the end of May the surface to bottom difference in temperature was $2.4^{\circ} \mathrm{C}$. Stratification persisted for the remainder of the study, but there was evidence of a mixing event in early June. On June 13 for example, the surface to bottom difference in temperature had fallen to $1.6^{\circ} \mathrm{C}$ and the $10.4^{\circ} \mathrm{C}$ isotherm extended to the sea-bed. Bottom water temperature increased from 9.0 to $10.7^{\circ} \mathrm{C}$ between March 1 and July 3.

\section{Water column nitrate}

Nitrate concentrations reached their winter maxima ( 9.0 $\mathrm{MM}$ ) during late March (Fig. 2B). As the spring bloom developed, near surface concentrations of nitrate were depleted and fell to between 0.46 and $0.51 \mu \mathrm{M}$ in June. Bottom water concentrations of nitrate remained relatively constant during the spring bloom period. The reduction in bottom water nitrate concentration coincided with the increase in bottom water temperature at the end of June.

\section{Development of the spring bloom}

Initiation of the spring bloom coincided with stratification of the water column and the development of a shallow $(-30 \mathrm{~m})$ surface mixed layer at the end of April. The bloom lasted approximately 1 mo (Fig. 2C). Peak chlorophyll biomass $\left(6.48 \mathrm{mg} \mathrm{chl} \mathrm{\textrm {m } ^ { - 3 }}\right)$ and

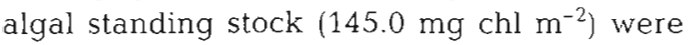
measured on May 11, following which the bloom declined. Deepening of the chlorophyll isopleths suggested settlement or downward mixing of the bloom in early May (Fig. 2C).

\section{Sediment characteristics}

The sediments were dominated by silt/clay particles $(93 \%)$ with an average porosity of $0.77(\mathrm{v} / \mathrm{v})$. The average $(\mathrm{n}=26)$ organic $C$ content was $1.5 \%$ (dry wt) with a C:N ratio of $17: 1$ (by wt). Total sediment pigment ( $\geq 82 \%$ phaeopigment) increased from 13.36 to $57.61 \mathrm{mg} \mathrm{m}^{-2}$ between March 30 and July 3 (Fig. 3). Chlorophyll and phaeopigment decreased with depth in July (Fig. 4). However, $14.3 \mathrm{mg} \mathrm{m}^{-2}$ of phaeopigment remained at $30 \mathrm{~cm}$ depth compared to only $0.72 \mathrm{mg} \mathrm{m}^{-2}$ of chlorophyll (Fig. 4).

\section{Rate measurements}

Maximum rates of sedimentary oxygen uptake (1658 $\mu \mathrm{mol} \mathrm{O}_{2} \mathrm{~m}^{-2} \mathrm{~h}^{-1}$ ) were measured in early May, but by July oxygen uptake (664 $\left.\mu \mathrm{mol} \mathrm{O}_{2} \mathrm{~m}^{-2} \mathrm{~h}^{-1}\right)$ was similar to that measured in February $\left(511 \mu \mathrm{mol} \mathrm{O} \mathrm{m}^{-2}\right.$ $\mathrm{h}^{-1}$ ) (Fig. 5A) and late summer (September 1996). Although there were visible differences between the measured rates of oxygen uptake, only the rates measured during the first cruise in May were significantly different (2-way ANOVA, $p<0.05$ ) to those measured on other occasions, i.e. May > April and July. The overall average rate of oxygen uptake, for 1998, was $924 \mu \mathrm{mol} \mathrm{O} \mathrm{m}^{-2} \mathrm{~h}^{-1} \pm 119$ ( $\mathrm{SE}, \mathrm{n}=18$ ).

The initial denitrification trial showed that there was no significant effect of elevated concentrations of ${ }^{15} \mathrm{NO}_{3}{ }^{-}$on measured in situ rates of denitrification. Denitrification supported by the flux of $\mathrm{NO}_{3}{ }^{-}$from the overlying water $\left(D_{w}\right)$ remained constant from February to late May, but increased significantly during July (2way ANOVA, p $<0.05$, Fig. 5B). Denitrification coupled to the nitrification of porewater $\mathrm{NH}_{4}{ }^{+}\left(\mathrm{D}_{\mathrm{n}}\right)$ followed a similar trend, with maximal rates being measured in late May and early July. Coupled nitrification-denitrification $\left(D_{n}\right)$ made up the greatest fraction of total denitrification, with an average of $79 \%\left(D_{n}\right)$ and $21 \%$ for

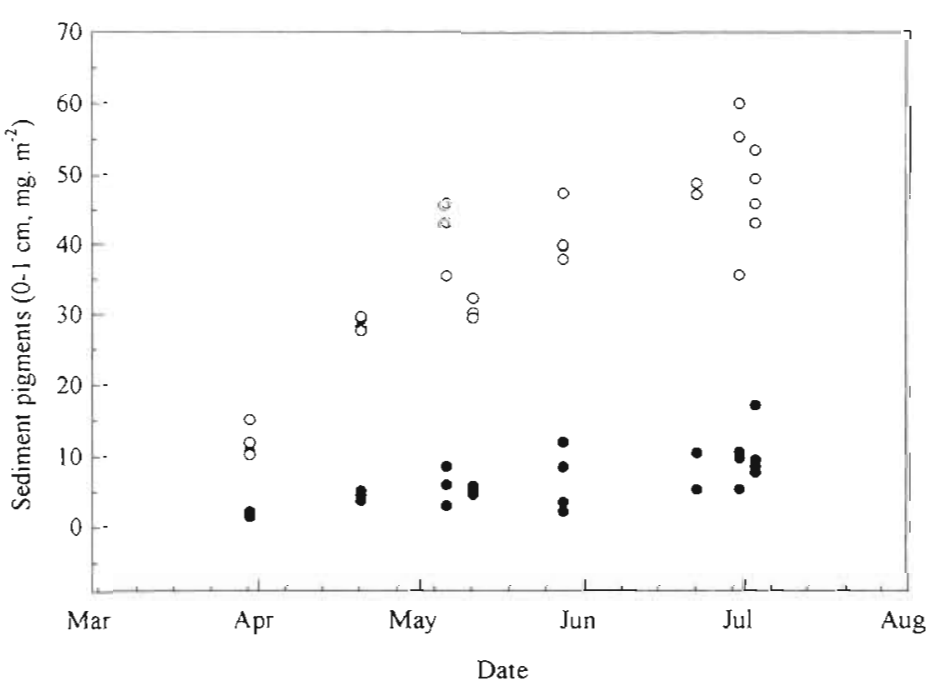

Fig. 3. Surficial sediment pigments $(0$ to $1 \mathrm{~cm})$, chlorophyll $(\bullet)$ and phaeopigment (o) during spring and early summer 1998 
$\mathrm{D}_{\mathrm{w}}$. The rates measured during the cruise in September 1996 are also shown for a late summer comparison.

Rates of sedimentary sulphate reduction (Fig. 5C), measured at all depths, did not vary significantly $(p<0.05)$ from February to late May $\left(11\right.$ to $22 \mu \mathrm{mol} \mathrm{SO}_{4}{ }^{2-} \mathrm{m}^{-2} \mathrm{~h}^{-1}$ over 0 to $15 \mathrm{~cm}$ ). However, the rates increased significantly ( 2 -way ANOVA, p < 0.05 ) at 0 to $5 \mathrm{~cm}$ and 11 to $15 \mathrm{~cm}$ during July $\left(81 \mu \mathrm{mol} \mathrm{SO}_{4}{ }^{2-} \mathrm{m}^{-2} \mathrm{~h}^{-1}\right)$.

Only the sediment-water exchange rates measured for $\mathrm{SiO}_{3}{ }^{2-}$ and $\mathrm{NO}_{3}{ }^{-}$were significantly greater than zero. The exchange rates for $\mathrm{NO}_{3}{ }^{-}$were the same on every occasion (ANCOVA) and were therefore expressed as an overall average $\left(10 \mu \mathrm{mol} \mathrm{NO}{ }_{3}^{-} \mathrm{m}^{-2} \mathrm{~h}^{-1} \pm 3 ; \mathrm{SE}, \mathrm{n}\right.$ =93). The exchange rates for $\mathrm{SiO}_{3}{ }^{2-}$ were greatcst during July (50 11mol $\mathrm{SiO}_{3}{ }^{2-} \mathrm{m}^{-2} \mathrm{~h}^{-1}$ ) and the rates measured in both early May and July were significantly greater than those measured in March, April or late May $(p<0.05)$

\section{DISCUSSION}

\section{Spring bloom}

The development of the spring bloom in relation to the onset of stratification is consistent with the vertical processes view of phytoplankton growth. Thus, the timing of bloom initiation is controlled by the underwater light climate as a function of surface mixed layer depth (Sverdrup 1953, Smetacek \& Passow 1990, Tett 1990). Chlorophyll standing stock was lower during the 1998 spring bloom compared to other years. For example, in 1997 Gowen et al. (1999) estimated maximum algal standing stock as $199 \mathrm{mg} \mathrm{chl} \mathrm{m}^{-2}$ compared to $145 \mathrm{mg} \mathrm{chl} \mathrm{m}^{-2}$ in 1998 . In other respects such as timing and duration (Fig. 2) the 1998 bloom was similar to previous descriptions (Gowen et al. 1995, 1999).

\section{Sedimentary processes}

There are no previous published studies of oxygen uptake, denitrification and sulphate reduction in the sediments of the western Irish Sea. The average rate of oxygen uptake $\left(924 \mu \mathrm{mol} \mathrm{O}_{2} \mathrm{~m}^{-2} \mathrm{~h}^{-1}\right)$ in these sediments was consistent with published values from northern European coastal and shelf waters. At 2 muddy sites in the North Sea, Upton et al. (1993) estimated average rates of oxygen uptake as $430181 \mathrm{~m}$ water depth) and 501 (52 $\mathrm{m}$ water depth) $\mu \mathrm{mol} \mathrm{O}_{2} \mathrm{~m}^{-2}$ $\mathrm{h}^{-1}$. The North Sea sites were not as muddy as the Irish Sea site, with a maximum of only $30 \%$ of particles

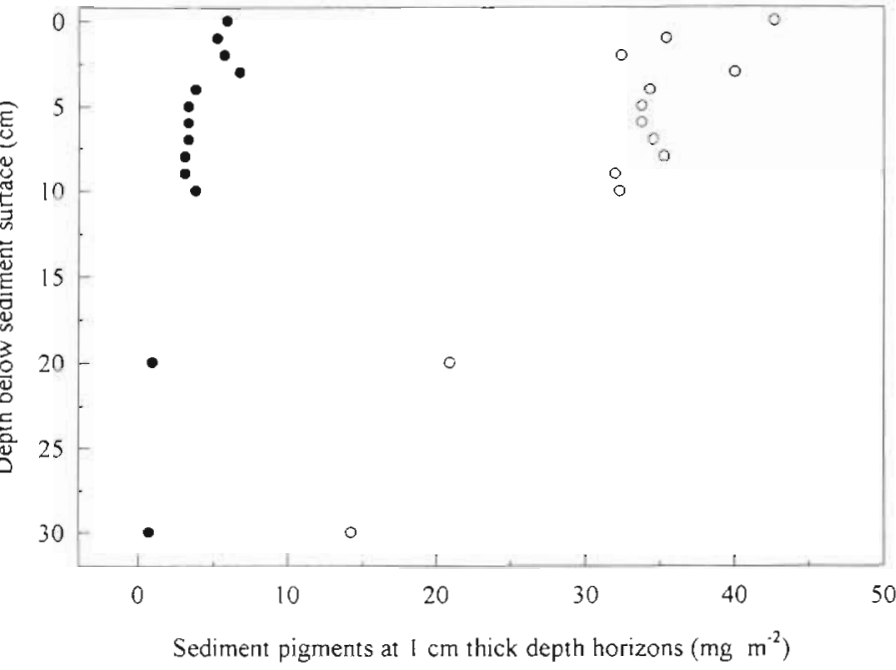

Fiq. 4. Sediment pigment depth profile $(0$ to $30 \mathrm{~cm})$, chlorophyl] ( and phaeopigment (o) measured in July 1998

$<63 \mu \mathrm{m}$, compared to $93 \%$ in the latter. Van Raaphorst et al. (1992) give a seasonal rate of 625 to $1666 \mu$ moi $\mathrm{O}_{2}$ $\mathrm{m}^{-2} \mathrm{~h}^{-1}$ for the Frisian Front (>20\% mud and $39 \mathrm{~m}$ depth) in the North Sea. Lohse (1994) reported rates of between 221 and $987 \mu \mathrm{mol} \mathrm{O}_{2} \mathrm{~m}^{-2} \mathrm{~h}^{-1}$ for 2 muddy sites (>50\% silt) in the Skagen and Helgol Bight (North Sea) respectively.

Of the few studies made on denitrification in temperate marine sediments, only one (Lohse et al. 1996) has used the isotope pairing technique of Nielsen (1992). Lohse et al. (1996) reported an average rate for $D_{w}$ of $0.5 \mu \mathrm{mol} \mathrm{N} \mathrm{m}^{-2} \mathrm{~h}^{-1}$ for low organic $\mathrm{C}(0.12 \%$ dry wt) sediments in the North Sea, which is at the lower end of the western Irish Sea range of 0.3 to $33 \mu \mathrm{mol} \mathrm{N} \mathrm{m} \mathrm{N}^{-2}$ $\mathrm{h}^{-1}$. They also reported an average rate for $D_{n}$ of $11 \mu \mathrm{mol} \mathrm{N} \mathrm{m} \mathrm{N}^{-2} \mathrm{~h}^{-1}$, which is also at the lower end of our range of 3 to $81 \mu \mathrm{mol} \mathrm{N} \mathrm{m}^{-2} \mathrm{~h}^{-1}$. The higher denitrification rates measured in the stratified region reflect the higher organic C content (up to $1.5 \%$ dry wt) of these sediments. Lohse et al. (1996) also found that $96 \%$ of their total denitrification was coupled to nitrification $\left(D_{n}\right)$, which agrees well with our $D_{n}$ value of $79 \%$, and supports the hypothesis that in areas of low $\mathrm{NO}_{3}{ }^{-}$concentrations, e.g. offshore, the percentage of denitrification coupled to nitrification increases (Seitzinger et al. 1980).

Rates of benthic sulphate reduction ( 0 to $15 \mathrm{~cm}$ ) were markedly lower ( 11 to $81 \mu \mathrm{mol} \mathrm{SO}{ }^{2-} \mathrm{m}^{-2} \mathrm{~h}^{-1}$ ) than rates reported in the literature. Upton et al. (1993) give average rates of 160 to $254 \mu \mathrm{mol} \mathrm{SO}{ }_{4}{ }^{2-} \mathrm{m}^{-2} \mathrm{~h}^{-1}$ for their 2 muddy sites in the North Sea. Although the data from Upton et al. (1993) were integrated over 0 to $25 \mathrm{~cm}$, compared to 0 to $15 \mathrm{~cm}$ in our study, $80 \%$ of their activity was measured between 0 and $15 \mathrm{~cm}$. At a high 

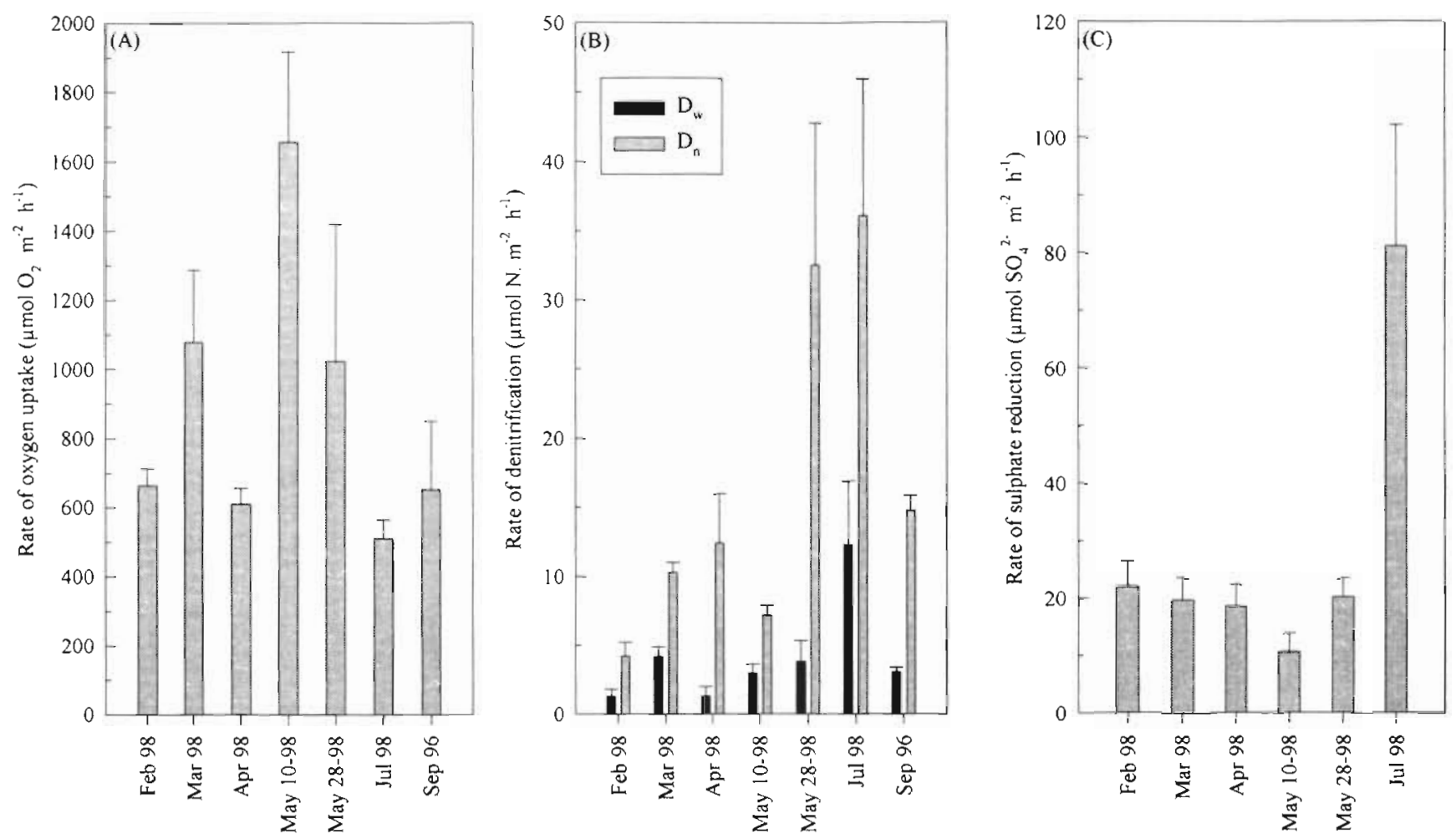

Fig. 5. Sediment respiration rates for (A) oxygen uptake and (B) denitrification, bars indicate standard error, $n=3$ and 6 respectively. Additional measurements from September 1996 are also shown for a late summer comparison. $D_{\mathrm{w}}$ : denitrification supported by the uptake of $\mathrm{NO}_{3}^{-}$from the overlying water $\mathrm{D}_{\mathrm{n}}$ : denitrification coupled to the nitrification of porewater $\mathrm{NH}_{4}^{+}$.

(C) Sulphate reduction (integrated over 0 to $15 \mathrm{~cm}$ ), bars indicate standard error, $\mathrm{n}=3$

deposition site (70 $\mathrm{m}$ depth) in the Kattegat, Jørgensen et al. (1990) measured maximum rates of sulphate reduction at $15 \mathrm{~cm}\left(\geq 1.6 \mathrm{nmol} \mathrm{SO}{ }_{4}{ }^{2-} \mathrm{cm}^{-2} \mathrm{~h}^{-1}\right)$ which is an order of magnitude higher than our average rate of $0.14 \mathrm{nmol} \mathrm{SO}_{4}{ }^{2-} \mathrm{cm}^{-2} \mathrm{~h}^{-1} \pm 0.02(\mathrm{SE}, \mathrm{n}=15$, excluding July) at $15 \mathrm{~cm}$.

In the stratified region measured rates of sulphate reduction were essentially constant from 0 to $15 \mathrm{~cm}$. Typically rates of sulphate reduction peak at $\sim 5 \mathrm{~cm}$ and then decrease with sediment depth (Jørgensen 1977. Nedwell \& Takii 1988, Nedwell 1989, Sagemann et al. 1998). Sulphate is abundant in surficial sediment and the rate of sulphate reduction is more likely to be limited by low availability of organic $\mathrm{C}$ or seasonal drop in temperature (Nedwell \& Abram 1979, Boudreau \& Westrich 1984, Sagemann et al. 1998). As the concentration of sulphate in the Irish Sea sediments was not limiting, and temperature remained essentially constant $\left(\Delta T 1.4^{\circ} \mathrm{C}\right)$ the homogeneous distribution of sulphate reduction to $15 \mathrm{~cm}$ suggested that labile organic $C$ was distributed relatively evenly throughout the surficial sediment. The depth profile of sediment pigments (Fig. 4) supports this interpretation.

Jørgensen (1982) carried out a detailed survey of both oxygen uptake and sulphate reduction at 58 sta- tions in Danish fjords and seas. He predicted a 7:1 ratio between the 2 variables for sediments collected from depths of 20 to $200 \mathrm{~m}$, provided oxygen uptake was $\geq 800 \mu \mathrm{mol} \mathrm{O}_{2} \mathrm{~m}^{-2} \mathrm{~h}^{-1}$. Our average rate of oxygen uptake was $924 \mu \mathrm{mol} \mathrm{O} \mathrm{m}^{-2} \mathrm{~h}^{-1}$, but the ratio of oxygen uptake to sulphate reduction was $42: 1$ (median). This further suggests that our integrated rates of sulphate reduction are too low and that higher rates of sulphate reduction were occurring below $15 \mathrm{~cm}$. A similar situation was observed by Jørgensen et al. (1990) in the muddy sediment of the Baltic/North Sea transition area. These authors concluded that $50 \%$ of sulphate reduction occurred below $15 \mathrm{~cm}$ because sedimentation rates were high and there was deep mixing of organic material. In the stratified region of the western Irish Sea, a combination of bioturbation by Nephrops norvegica and beam trawling may have been responsible for mixing of the surficial sediment layer and extension of the sulphate reduction zone. This mixing, firstly, oxidises the surficial sediment and reduces the rates of sulphate reduction in these layers; but, secondly, by mixing organic material down into the sediment it also extends downward the depth of the zone of active sulphate reduction. The eventual fate of this buried organic material remains unknown. 


\section{Coupling between the spring bloom and sedimentary processes}

The small seasonal change in bottom water temperature $10.1^{\circ} \mathrm{C}$ up to the end of the spring bloom and $1.4^{\circ} \mathrm{C}$ overall) provided an opportunity to measure the effect. of changes in organic $C$ availability on sediment respiration; effects that can often be masked by seasonal temperature fluctuations. An increase in sediment oxygen uptake was measured in early May, which coincided with deepening of the chlorophyll isopleths (Fig. 2C). This suggests that settling of the spring bloom to the sea-bed fuelled the measured increase in sediment oxygen consumption. Mixing of this organic material throughout the upper $30 \mathrm{~cm}$ of the sediment (Fig. 4) in turn stimulated denitrification (late May and early July) and eventually sulphate reduction.

Sediment tompcratures in the Antarctic fluctuate around a similarly narrow (although lower) range, e.g. -1.8 to $+1^{\circ} \mathrm{C}$ (Nedwell 1989), to that of the bottom water in the western Irish Sea. Nedwell et al. (1993) concluded that periodic inputs of organic material elevated the organic content of the surface sediment and in turn stimulated oxygen uptake. This organic enrichment of the surface sediment was attributed to the settlement of ice algae following the spring melt. In addition, the proportion of anaerobic mineralisation compared to aerobic mineralisation increased during the winter as organic matter was buried by the amphipod infauna (Nedwell et al. 1993). In the Irish Sea, the proportion of mineralisation via sulphate reduction, compared to aerobic mineralisation, increased from an average of $2 \%$ between February and late May to $16 \%$ in July. This may have been due to burial of organic material, although the relative importance of bioturbation by benthic fauna and sediment disturbance by trawling has yet to be determined.

There was no significant efflux of $\mathrm{NH}_{4}{ }^{+}$or urea from the sediment and the sum of $\mathrm{D}_{\mathrm{n}}$ and $\mathrm{NO}_{3}{ }^{-}$efflux can be assumed to be the same as the total rate of organic $\mathrm{N}$ ammonification. Since all the ammonified organic $\mathrm{N}$ was in turn oxidised to $\mathrm{NO}_{3}{ }^{-}$, the total rate of organic $\mathrm{N}$ ammonification also represented the rate of nitrification. Denitrification accounted for an average $63 \%$ of the ammonified organic $\mathrm{N}$, with the remaining $27 \%$ exchanging with the overlying water as $\mathrm{NO}_{3}{ }^{-}$. Lohse et al. (1996) reported values of $35 \%$ and $32 \%$, respectively, for these 2 processes in low organic North Sea sediments. Nitrification and sulphate reduction both accounted for an average of $9 \%$ of the oxygen uptake budget $(18 \%$ in total)

The degree of coupling between water column production during the spring bloom and benthic processes can be assessed by building a simple $C$ budget. Daily total production was estimated from chlorophyll stand- ing stock using the relationship between stock and water column production (Gowen \& Bloomfield 1996 Gowen et al. 1999):

In production $=$

$0.637 \times$ (ln chlorophyll standing stock +3.625 )

and integrating between sampling dates. On this basis total production (new: from winter $\mathrm{NO}_{3}{ }^{-}$; and regenerated: from recycled nitrogen; Dugdale \& Goering 1967) between February and July was estimated as $44.8 \mathrm{~g} \mathrm{C}$ $\mathrm{m}^{-2}$ of which $-70 \%$ (31.4 $\left.\mathrm{g} \mathrm{C} \mathrm{m}^{-2}\right)$ was produced during the spring bloom. As a comparison, spring bloom production can be estimated from the draw down of winter $\mathrm{NO}_{3}{ }^{-}$and a $\mathrm{C}: \mathrm{N}$ ratio of 7:1. Between March 30 (the winter $\mathrm{NO}_{3}{ }^{-}$maximum) and May 11, water column $\mathrm{NO}_{3}{ }^{-}$decreased by $282 \mathrm{mmol} \mathrm{m}^{-2}$, which gives a production of $23.7 \mathrm{~g} \mathrm{C} \mathrm{m}^{-2}$, close to the $31.4 \mathrm{~g} \mathrm{C} \mathrm{m}^{-2}$ for total production. The ratio of new to total production (the $f$ ratio of Eppley \& Peterson 1979) of 0.76 indicates that the spring bloom comprised $76 \%$ new production and $24 \%$ regenerated production.

By subtracting the mean pre and post spring bloom (February, March, July and September) rate of oxygen uptake $\left(600 \mu \mathrm{mol} \mathrm{m} \mathrm{m}^{-2} \mathrm{~h}^{-1}\right)$ from the total integrated oxygen uptake rate the increase in oxygen consumption in response to input of detritus (assumed to be largely phytodetritus immediately after the spring bloom) was estimated as $1.2 \mathrm{~mol} \mathrm{O}_{2} \mathrm{~m}^{-2}$. This represents $46 \%$ of total spring production ( $61 \%$ of new production) and is comparable to estimates of 17 to $45 \%$ in the southern North Sea (Upton et al. 1993) and 55\% in the Georgia Bight (Hopkinson \& Wetzel 1982).

It is evident that there is sufficient production in the overlying water column to support oxygen consumption in the benthos. However, there are no published measurements of detrital $C$ flux to the benthos for this region of the Irish Sea. An estimate of detrital $C$ flux (Flux $\mathrm{C}_{\text {org }}$ ) to the sea-bed can be obtained using the empirical relationship between production and water depth (Suess \& Müller 1980):

$$
\text { Flux } \mathrm{C}_{\text {org }}=5.9 \times \text { depth }^{-0.616} \times \text { productivity }
$$

Taking water depth to be $93 \mathrm{~m}$ input to the benthos would be $11.3 \mathrm{~g} \mathrm{C} \mathrm{m}^{-2}\left(0.94 \mathrm{~mol} \mathrm{C} \mathrm{m}^{-2}\right)$ or $36 \%$ of total spring bloom production, which is similar to the input calculated from oxygen uptake $\left(1.2 \mathrm{~mol} \mathrm{O}_{2} \mathrm{~m}^{-2}\right)$. From an empirical relationship which relates sedimentation to $C$ supply and mixed layer depth (Parsons et al. 1977) the flux of $\mathrm{C}$ to the benthos can be estimated as $10.2 \mathrm{~g}$ $\mathrm{C} \mathrm{m}^{-2}\left(0.85 \mathrm{~mol} \mathrm{C} \mathrm{m} \mathrm{m}^{-2}\right)$ or $32 \%$ of spring bloom production. Both empirical relationships underestimate the supply of $C$ to the benthos necessary to support the measured increase in oxygen uptake.

There was little evidence of a large flux of phytodetritus to the benthos during the spring of 1998. Clearly, 
there was an input of organic $C\left(\sim 1.2 \mathrm{~mol} \mathrm{C} \mathrm{m}^{-2}\right)$ to fuel the increase in sediment oxygen consumption in early May. However, the sediment pigment data (Fig. 4) indicated a continual, but low, input of phytodetritus over the spring. Taken together, our results suggest that in 1998 between 32 and $46 \%$ of total spring production reached the benthos, but this input of detritus had only a short-lived impact on the benthos and organic $C$ would have been available to support secondary production, e.g. Nephrops norvegica. However, spring bloom production in the stratifed region appears to be quite variable. For example, in 1992 and 1993, production was estimated as 51.3 and $38.9 \mathrm{~g} \mathrm{C}$ $\mathrm{m}^{-2}$ respectively (data from Gowen \& Bloomfield 1996) compared to $28.2 \mathrm{~g} \mathrm{C} \mathrm{m}^{-2}$ in 1997 (Gowen et al. 1999) and $31.4 \mathrm{~g} \mathrm{C} \mathrm{m}^{-2}$ in this study. It would appear from our results that in some years the spring bloom only plays a minor role in benthic secondary production. In such years, benthic production, particularly that of $N$. norvegica, must be supported by phytoplankton production which takes place after the bloom or by detrital organic $\mathrm{C}$ which is advected into the area following the breakdown of the gyre.

Acknowledgements. This work was part of the JoNuS (Joint Nutrient Study) programme funded by the UK Ministry of Agriculture, Fisheries and Food, Department of the Environment, Transport and the Regions and Department of Agriculture for Northern Ireland. The views expressed are those of the authors and do not reflect the policies of the funding Departments. The authors would like to thank colleagues who assisted in the field programme and the Captain, Officers and crew of the RV 'Lough Foyle' and RV 'Cirolina'

\section{LITERATURE CITED}

Boudreau BP, Westrich JT (1984) The dependence of bacterial sulphate reduction on sulphate concentration in marine sediments. Geochim Cosmochim Acta 48:2503-2516

Briggs RP (1997) The Dublin Bay prawn. Biologist 44:246-248

Dickey-Collas M, Stewart BM, Gowen RJ (1996) The role of thermal stratification on the population dynamics of Sagitta elegans Verrill in the western Irish Sea. J Plankton Res 18:1659-1674

Dugdale RC, Goering JJ (1967) Uptake of new and regenerated forms of nitrogen in primary production. Limnol Oceanogr 12:196-206

Eppley RW, Peterson BJ (1979) Particulate organic matter flux and planktonic new production in the deep ocean. Nature 282:677-680

Fossing $H_{1}$ Jergensen BB (1989) Measurement of bacterial sulphate reduction in sediments: evaluation of a single-step chromium reduction method. Biogeochemistry 8:205-222

Gowen RJ, Bloomfield SP (1996) Chlorophyll standing crop and phytoplankton production in the western Irish Sea during 1992 and 1993. J Plankton Res 18:1735-1751

Gowen RJ, Stewart BM, Mills DK, Elliot P (1995) Regional differences in stratification and its effect on phytoplankton production and biomass in the northwestern lrish Sea. J Plankton Res 17:753-769
Gowen RJ, McCullough G, Kleppel GS, Houchin L, Elliott P (1999) Are copepods important grazers of the spring bloom in the western Irish Sea? J Plankton Res 21:465-483

Hill AE, Durazo R, Smeed DA (1994) Observations of a cyclonic gyre in the western Irish Sea. Cont Shelf Res 14: $479-490$

Hill AE, Brown J, Fernand L (1996) The western lrish Sea gyre: a retention mechanism for the Norway lobster (Nephrops norvegicus)? Oceanol Acta 19:357-368

Hopkinson CS, Wetzel RL (1982) In situ measurements of nutrient and oxygen fluxes in a coastal marine benthic community. Mar Ecol Prog Ser 10:29-35

Jorgensen BB (1977) The sulphur cycle of a coastal marine sediment (Limfjorden, Denmark). Limnol Oceanogr 22: $814-832$

Jørgensen BB (1982) Mineralisation of organic matter in the sea bed - the role of sulphate reduction. Nature 296: $643-645$

Jorgensen $B B$ (1983) Processes at the sediment-water interface. In: Bolin B, Cook RB (eds) The major biogeochemical cycles and their interactions. SCOPE. Wiley, Chichester, p 477-509

Jørgensen BB, Bang M, Blackburn TH (1990) Anaerobic mineralisation in marine sediments from the Baltic Sea-North Sea transition. Mar Ecol Prog Ser 59:39-54

Lohse L (1994) Sediment-water exchange of nitrogen compounds and oxygen in the North Sea. PhD thesis, University of Groningen

Lohse L, Kloosterhuis R, van Raaphorst W, Helder W (1996) Denitrification rates in continental shelf sediments of the North Sea: acetylene block technique versus isotope pairing. Mar Ecol Prog Ser 132:169-179

Nedwell DB (1989) Benthic microbial activity in an Antarctic coastal sediment at Signy Island, South Orkney Islands. Estuar Coast Shelf Sci 28:507-516

Nedwell DB, Abram JW (1979) Relative importance of temperature and electron donor and electron acceptor concentrations on bacterial sulphate reduction in saltmarsh sediments. Microb Ecol 5:67-72

Nedwell DB, Takii S (1988) Bacterial sulphate reduction in sediments of a European saltmarsh: acid-volatile and tinreducible products. Estuar Coastal Shelf Sci 26:599-606

Nedwell DB, Trimmer M (1996) Nitrogen fluxes through the upper estuary of the Great Ouse, England: the role of the bottom sediments. Mar Ecol Prog Ser 142:273-286

Nedwell DB, Walker TR, Ellis-Evans JC, Clarke A (1993) Measurements of seasonal rates and annual budgets of organic carbon fluxes in an Antarctic coastal environment at Signy Island, South Orkney Islands, suggest a broad balance between production and decomposition. Appl Environ Microbiol 59:3989-3995

Nielsen LP (1992) Denitrification in sediment determined from nitrogen isotope pairing. FEMS Microbiol Ecol 86: $357-362$

Parsons TR, Takahashi M, Hargrave B (1977) Biological oceanographic processes, 2nd edn. Pergamon Press, Oxford

Richardson K, Lavin-Peregrina MF, Mitchelson EG, Simpson JH (1985) Seasonal distribution of chlorophyll a in relation to physical structure in the Western Irish Sea. Oceanol Acta 8:77-85

Rysgaard S, Christensen PB, Nielsen LP (1995) Seasonal variation in nitrification and denitrification in estuarine sediment colonised by benthic microalgae and bioturbating infauna. Mar Ecol Prog Ser 126:111-121

Sagemann J, Jørgensen BB, Greeff O (1998) Temperature dependence and rates of sulphate reduction in cold sedi- 
ments of Svalbard, Arctic Ocean. J Geomicrobiol 15 $85-100$

Seitzinger S, Nixon S, Pilson MEQ, Burke S (1980) Denitrification and $\mathrm{N}_{2} \mathrm{O}$ production in near-shore marine sediments. Geochim Cosmochim Acta 44:1853-1860

Simpson JH, Hunter JR (1974) Fronts in the Irish Sea. Nature 250:404-406

Skyring GW (1985) Anaerobic microbial processes in coral reef sediments. In: Gabrie C, Toffart JL, Salvat B (eds) Proceedings of the 5th International Coral Reef Congress, Tahiti, May 27-June 1 1985, Vol 3, p 421-425

Smetacek V, Passow U (1990) Spring bloom initiation and Sverdrup's critical-depth model Limnol Oceanogr 35:228-234

Sorokin YL (1962) Experimental investigation of bacterial sulphate reduction in the Black Sea using ${ }^{35} \mathrm{~S}$. Mikrobiologiya $31: 402-410$

Stewart BM, Elliot PAW (1996) Systematic salt effects in the automated determination of nutrients in seawater. Water Res 30:869-874

Suess E, Müller PJ (1980) Productivity, sedimentation rate and sedimentary organic matter in the oceans. II. Elemental fractionation. Colloques Internationalux du CNRS. No. 293. Biogéochimie de la matière organique à l'interface eau-sédiment marin. CNRS, (Marseille) p 17-26

Editorial responsibility: Otto Kinne (Editor),

Oldendorf/Luhe, Germany
Sverdrup HU (1953) On the conditions for the vernal blooming of phytoplankton. J Cons Int Explor Mer 18: $287-295$

Tait RV (1981) Elements of marine ecology, 3rd edn. Butterworths, London

Tett P (1987) Plankton. In: Baker JM, Wolff WM (eds) Biological surveys of estuaries and coasts. Cambridge University Press, Cambridge, p 280-341

Tett P (1990) The photic zone. In: Herring PJ, Campbell AK, Whitfield $M$, Maddock L (eds) Light and life in the sea. Cambridge University Press, Cambridge, p 59-87

Upton AC, Nedwell DB, Parkes RJ, Harvey SM (1993) Seasonal benthic microbial activity in the southern North Sea; oxygen uptake and sulphate reduction. Mar Ecol Prog Ser 101:273-281

Van Raaphorst W, Kloosterhuis HT, Berghuis EM, Gieles AJM, Malschaert JFP, van Noort GJ (1992) Nitrogen cycling in two types of sediments of the southern North Sea (Frisian Front, Broad Fourteens): field data and mesocosm results. Neth J Sea Res 28:293-316

White RG, Hill AE, Jones DA (1988) Distribution of Nephrops norvegicus (L.) larvap in the western Irish Sea, an example of advective control on recruitment. J Plankton Res 10 : $735-747$

Submitted: December 16, 1998; Accepted: April 19, 1999 Proofs received from author(s): August 2, 1999 


\section{Erratum}

\section{The spring bloom and its impact on benthic mineralisation rates in western Irish Sea sediments}

M. Trimmer, R. J. Gowen, B. M. Stewart, D. B. Nedwell

Mar Ecol Prog Ser 185:37-46

- On page 45, the word 'little' was omitted in the last paragraph of the text. The third sentence on the page should read 'Taken together, our results suggest that in 1998 between 32 and $46 \%$ of total spring production reached the benthos, but this input of detritus had only a short-lived impact on the benthos and little organic $\mathrm{C}$ would have been available to support secondary production e.g. N. norvegica.' 